\title{
The Struggle for Byelorussia's Autonomy in the First Slate Duma
}

\author{
(27 April/10 May - 7/20 June 1906)
}

BY

\author{
JAN ZAPRUDNIK
}

\section{A NOTE ON TERMINOLOGY}

Before 1917 Byelorussia (or parts of it) was called by various names, imprecise and overlapping: the North-Western Region (Severo-zapadnyj Kraj), the Western Region (Zapadnyj Kraj), the North-Western gubernijas, the Western gubernijas, the Western and Byelorussian gubernijas (gubernii Zapadnyje $i$ Belorusskije), the Byelorussian and Lithuanian gubernijas (gubernii Belorusskije i Litovskije), Lithuania (Litva), Rus', Belaja Rus', Western Russia, or simply Russia. In this compendium of names one probably finds the most dramatic reflection of the historical changes, disputes and claims that convulsed the area, which for over three hundred years had been at stake in the clash between Polish and Russian expansionist ambitions.

Terminology is the key to understanding both the historical processes and the political history of Byelorussia. A Soviet historian, Jazep Jucho, recently noted: '... Confusion in terminology leads to distortion of the whole historical process of development of the Byelorussian people...'1

Of the above cited names, the most often used was the 'Severozapadyj Kraj', the North-Western Region, which at the same time was never strictly defined and whose extent varied with different speakers and authors. In the State Duma, in 1914, for example, the term was given its broadest sense by A. P. Fotinskij, the Agricultural Committee speaker, and the delegate of the Minsk gubernija:

'The North-Western Region, which could be said to include the Byelorussian gubernijas of Mahiloŭ, Viciebsk, Minsk and Smolensk, as well as the Lithuanian gubernijas of Vilna, Kovno and Hrodna, and part of the lake-land gubernijas of Novgorod and Pskov, constitutes a separate region with its own economic and agricultural characteristics.'

Usually, however, the term North-Western Region was employed

1. J. Jucho, 'Pra nazvu "Biełaruś" ', Polymia, 1, Minsk, 1968, p. 181.

2. Gosudarstvennaja Duma. Stenografičeskije Otčety, (subsequently referred to as SO), StP, 1914, Fourth Duma, Session 2, Part 2, col. 1874, 18 March 1914. 
in relation to six gubernijas - those of Kovno, Vilna, Hrodna, Minsk, Viciebsk and Mahiloŭ. In this sense it was applied in statistics, administrative practice, and most periodical literature. Sometimes the North-Western Region was reduced to only the three westernmost gubernijas of Vilna, Kovno and Hrodna, and in this sense it was used at times synonymously with 'Lithuania'.

The North-Western gubernijas were sometimes referred to as 'Western'. In his demographic studies Lenin, for instance, subdivided European Russia into nine parts, of which one, the 'Western', consisted of the six gubernijas: Kovno, Vilna, Hrodna, Minsk, Viciebsk and Mahiloŭ.

It was on account of such confusion, even by experts, that in the third Duma, Matjunin, speaking for the Editorial Committee, explained:

'Actually, there are no 'Western gubernijas'. When we say 'Western' we should add 'nine' because we have 'North-Western' and 'South-Western'. Combined, the Western and Byelorussian gubernijas ... should include nine Western, because the gubernijas of Mahiloŭ, Minsk and Viciebsk, which are considered to be Byelorussian, are part of the six North-Western gubernijas; the six North-Western and the three South-Western (those of Kiev, Podol'sk and Volhynia - J.Z.) legally constitute the so-called nine Western gubernijas."

In any discussion of Byelorussian history it should be borne in mind that before 1917 the geographic designations 'Lithuania' and 'Byelorussia' did not coincide with the ethnographic attributes of their respective areas, and consequently do not coincide with the meaning of the same words today. As one authority has observed on this subject: 'Just as the term "Lithuania" was applied to a territory larger than that occupied by the Lithuanian people, so the terin "Byelorussia" fell short of covering the territory inhabited by Byelorussians'.

\section{REPRESENTATION OF BYELORUSSIA IN THE FIRST STATE DUMA}

In the North-Western Region elections to the first Duma (FebruaryMarch 1906) were held in an atmosphere of mixed hopes, confusion and nationalistic tension. 'I ran into great difficulties', wrote diarist Alexander Lednicki who had come from his residence in Moscow to Minsk to run for the Duma on the Cadet ticket. 'Slogans of chauvinistic nationalism, complete confusion and total lack of popular understanding of the practical significance of the election, and a complete absence of any future plans whatsoever, naturally prevailed. ${ }^{5}$ There were people however who had a vision of the

3. SO, Third Duma, Session 4, Part 3, cols 1616-1617, 24 March 1911.

4. N. N. Ulaščik. Predposylki krest'janskoj reformy $1861 \mathrm{~g}$. $v$ Litve $i$ Zapadnoj Belorussii, Moscow, 1965, p. 6, n. 2.

5. W. Lednicki, Pamiętniki, II, London, 1967, p. 532. 
future and understood the potentialities of the electoral contest. Initially they fell into various groups, more numerous than those in the central parts of Russia where the Cadets were strongest. 'On the borderlands', wrote the vigilant monarchist Okrainy Rossii, comparing the border situation with that of the central gubernijas, 'something else could be observed. There were parties of various kinds: the Party of Lawful Order, the Party of October 17th, in some areas the Monarchist Party, the Social Democratic, and especially the Cadet Party, but the irresoluteness of the Cadet Party there became increasingly apparent and now a regrouping is underway.' 'Regrouping' worked its way along national lines as Okrainy Rossii had reported earlier: 'At present, on the eve of the election, there are only three parties in Minsk: the Jewish, the Polish and the Party of October $17 \mathrm{th}$... The Poles and Jews united into national groups without hesitation, without any party differences.' ${ }^{7}$ The Byelorussian Socialist Hramada, the only possible organizer of the Byelorussian national element, boycotted the election together with other leftist socialist parties. $^{8}$ The call for a boycott, however, if it was loud enough to be heard at all, had only a weak echo: peasants participated widely in the election and boycotting was 'rare'.9

The results of the election to the first State Duma in five Byelorussian gubernijas are presented in the following table:

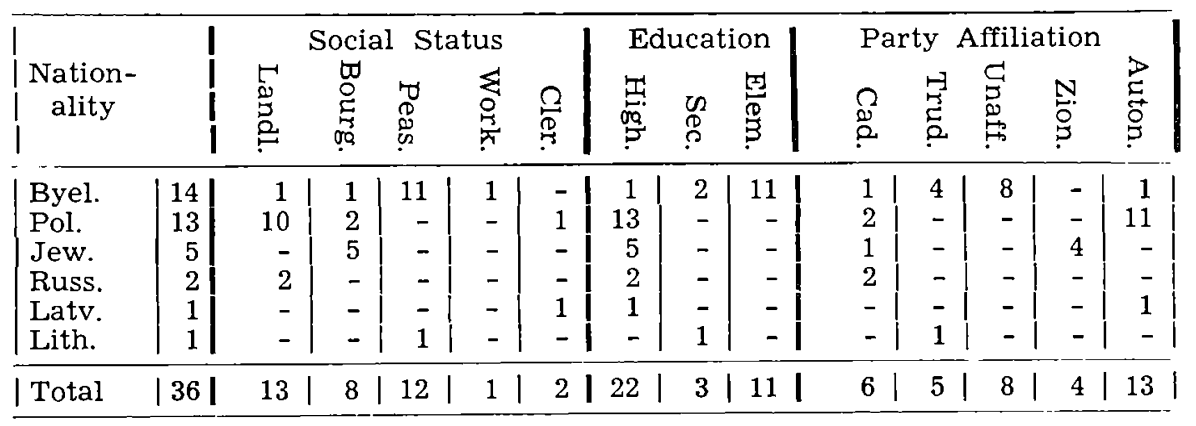

Calculated from: Gosudarstvennaja Duma pervogo sozyva. Portrety, kratkije biografii $i$ charakteristiki deputatov, StP, 1906; Pervaja

6. Okrainy Rossii, 16 April 1906, p. 121.

7. Okrainy Rossii, 26 March 1906, p. 74.

On the conditions promoting co-operation between the Byelorussian and Jewish population in the North-Western Region at the end of the 19th and the beginning of the 20 th centuries, see N. Nedasek, Bol'ševizm v revoljucionnom dviženii Belorussii, Munich, 1956, pp. 51-52, 69-71.

A common front among the Poles, Ukrainians. Byelorussians and Lithuanians is noted by W. Lednicki, Pamiętniki, I, p. 49.

8. N. Nedasek, op. cit., p. 124.

9. K. I. Sabunja, Agrarnyj vopros i krest'janskoje dviženije $v$ Belorussii $v$ revoljucii 1905-1907 gg., Minsk, 1962, p. 355. 
Gosudarstvennaja Duma. Alfavitnyj spisok i podrobnyje biografii $i$ charakteristiki členov Gosudarstvennoj Dumy, StP, 1906; Enciklopedičeskij Slovar' 'Granat', 7th edition, Moscow, s. a., XVII, Supplement, pp. 1-76; Novyj Enciklopedičeskij Slovar' Brokgauz-Jefron, StP, s. a., XIV, Supplement to the article 'State Duma', pp. i-lxxii; Russkaja Enciklopedija ed. (S. A. Adrianov et al.), StP, s. a., VI, the table on pp. 152-3; and other sources.

Some of the above figures, especially the number of Cadets, call for explanation. It is impossible to tag the deputies with neat party labels, paríicularly in a multinational area like the North-Western Region and at a time when political parties were only just emerging, with overlapping ideas and concepts. Thus, among the twelve autonomists, four Zionists, and eight otherwise unaffiliated, there were respectively, three, three and five members having Cadet leanings of varying intensity. The number of Cadets, therefore, could well be considered eighteen (50 per cent). Mainly because of their different approaches, various authors have given divers figures:

1. ' $15 \%$ rightists, $51 \%$ Cadets and Progressivists, $31 \%$ leftists and $2 \%$ Unaffiliated.' ${ }^{20}$

2. '24 landlord and bourgeois deputies and 12 peasant deputies.'11

3. 'Of 36 deputies elected from the five Western gubernijas, 10 belonged to the Cadet Party... There were 12 autonomists. Many held views close to those of the Cadets... Of 13 peasant deputies (actually, one of them was a railroad worker of peasant origin J. Z.), 5 joined the Trudovik group, 1 was close to the Cadets, and the remaining 7 declared themselves unaffiliated; however, 3 of them were Cadet sympathizers... Among the 36 deputies from the five Western gubernijas there were $10(28 \%)$ landlords, $2(5.4 \%)$ priests, $11(30.5 \%)$ bourgeois intellectuals (lawyers, writers), and 13 $(36.1 \%)$ peasants.' 12

Despite some discrepancies, the above sources largely corroborate our table. It should however be remembered that social and political categories cannot be consistently equated. The history of the State Duma provides plenty of examples of noble, clerical, bourgeois, or peasant deputies from the North-Western Region being sharply opposed politically to fellow deputies of the same social class. The issues that divided the deputies most were the question of autonomy for the Region and the religious and cultural policies of the Government. These issues crossed nationality lines, the latter, like many other terms of that peculiar time and place, requiring an explanation.

Officially, there were twelve Byelorussians in the first Duma. ${ }^{13}$ Eleven of them were peasants with only an elementary education and

10. F. Turuk, Belorusskoje dviženije, Moscow, 1921, p. 15, n. 2. One per cenit got lost in Turuk's calculation because his percentage figures only total 99 .

11. V. N. Percev et al. (eds), Istorija BSSR, Minsk, 1954, I, p. 400.

12. K. I. Sabunja, op. cit., pp. 355-6.

13. V. I. Ger'je, Pervaja russkaja Gosudarstvennaja Duma: političeskije vozzrenija $i$ taktika jejo členov, Moscow, 1906, p. 7; Russkaja Enciklopedija (ed. S. A. Adrianov et al.), StP, s. a., VI, the table on pp. 152-3. 
one was a railroad worker of peasant origin with a secondary education. Politically, eight of them were unaffiliated (four sympathizing with the Cadets) and four Trudoviks. Our table, however, shows the number to be fourteen. The reason for the difference is that two members of the first Duma, Roman Skirmunt of the Minsk gubernija and Aleksej Volkovič of the Viciebsk gubernija were registered according to the notions and practices prevailing among noblemen and bourgeois, as Pole and Russian respectively, Byelorussian nationality either being not recognized at all or else identified (hyphenated) with peasant status. Historically, however, and we believe objectively, Roman Skirmunt and Aleksej Volkovič, as well as some other deputies throughout the entire Duma period who were officially categorized as Polish or Russian, were not only natives of Byelorussia, but adhered to a school of thought that made some essential contributions to the rise of Byelorussian political nationalism and the eventual emergence of the Byelorussian political state. Representatives of these schools - Zapadno-Russizm (West-Russianism) ${ }^{14}$ and Polish Litwo-Rusizm (Lithuano-Ruthenianism) - were natives of the North-Western lands. Many of them, especially the nobility of Polish culture, had an acute sense of the history of the land and of their presence in it. They were aware of the ethnographic and political peculiarities of the area and of numerous instances of rivalry with the political centres in Moscow, St Petersburg or Warsaw in the past.

West-Russianism was epitomized by the ethnographer and historian Aleksej Sapunov, who in 1907-1912 represented the Viciebsk gubernija in the third Duma. Lithuano-Ruthenianism, on the other hand, was personified by the first Duma deputy Roman Skirmunt, a wealthy landlord of the Minsk gubernija. Immediately after the election, efforts were made by the leaders of Polish National Democracy, the party in control of the Polish delegation, to set up a tightly organized club of all the Polish deputies in the Duma. This club - the Polish Circle (Koło Polskie) - was, in fact, established, but without those who came from the so-called Western gubernijas. Out of rifty-five deputies of Polish nationality, only thirty-four those from Poland proper - became members of the Circle. Eighteen deputies from Lithuania, Byelorussia and the Ukraine as well as three from various cities of Russia did not join the Circle. ${ }^{15}$ The reason generally given for not joining was that they represented not one but many nationalities. There were, however, particular reasons, because in the opinion of many Polish nationalists the fact that he represented territory other than that of the Kingdom of Poland should not hinder a deputy of Polish nationality from belonging to the parliamentary Polish Circle. This was especially relevant to the North-Western gubernijas of Litwa and Rus', historically bound

14. For an excellent study on this subject see A. Cvikievič, Zapadno-russizm, Minsk, 1929.

15. Z. Eukawski, Koto Polskie w Rosyjskiej Dumie Państwowej w latach 19061909, Wrocław, 1967, pp. 30, 36. 
to Poland. The vital issue of the basis of organization became a matter of controversy, also revealing some significant clues to the question of political and national consciousness of that epoch and region.

In the summer of 1906, after the Duma had been dissolved and while the controversy over organizational tactics continued, a Polish newspaper in Kiev, Dziennik Kijowski, published an article by one 'Mr D.' (Roman Dmowski? - J. Z.). Mr D. explained that in the first Duma from the very beginning there had been opposition to creation even of 'a separate but certainly Polish national circle, allied with the group from the Kingdom itself'. One of those opposing that idea was Roman Skirmunt of whom Mr D. said:

'Mr Skirmunt first of all does not consider himself to be a Pole. In conversation with me he stated that he is a Byelorussian who only acquired Polish culture, that ... he has absolutely no need to number himself among those of Polish nationality to whom he is bound by culture. Mr Skirmunt, therefore, favoured establishment of a local Territorial Circle which would open wide its doors to Poles as well as Byelo- and Little-Russians, Lithuanians, Jews, and Russians. ${ }^{16}$

Holding essentially analogous reasons for his 'territorial separation' from the all-Polish Circle in the Duma was the deputy from the Vilna gubernija, a Catholic bishop, Baron Edward von der Ropp, a Latvian-born 'German in origin and Pole by convictions'.' In the autumn of 1905 Bishop Ropp founded and led the Constitutional Catholic Party ${ }^{18}$ which aimed at 'uniting Lithuanians, Byelorussian Catholics and local Poles on a common confessional-political platform without barring elements from other creeds'. ${ }^{19}$ Before its prohibition in 1906 the Party was active among the Byelorussian population ${ }^{20}$ and politically influential. ${ }^{21} \mathrm{Mr}$ D. of Dzieńnik Kijowski, who disputed the views of Bishop Ropp on the issue of a common political front with deputies from Poland, presented Ropp's attitude as follows:

'Considering himself a Pole, he was apprehensive lest Polish methods repel other nationalities such as the Lithuanians or Byelorussians, so that they separate themselves from the Polish deputies if the latter were suspected of harbouring plans for Polonization.'22

There are indications, however, of other fundamental differences between Bishop Ropp and the Dmowski school. In 1905 Bishop Ropp 'was nursing the idea of publishing in Vilna a popular Catholic newspaper in Byelorussian, but it was reported that his advisers were

16. Excerpts from Mr D's article were reprinted in Okrainy Rossii, 13 August 1906, D. 412.

17. Chryścijanskaja dumka, Vilna, 1 August 1939. p. 3.

18. Okrainy Rossii, 1 June 1906, pp. 241-3, discusses the history of the Party's programme which was progressive in social matters.

19. M. Roemer, 'Poljaki' in A. I. Kastelanskij (ed.), Formy nacional'nogo dviženija $v$ sovremennych gosudarstvach, StP, 1910, p. 370.

20. Okrainy Rossii, 26 March 1906, p. 74.

21. K. I. Sabunja, op. cit., pp. 381-2.

22. Okrainy Rossii, 13 August 1906, p. 412. 
very much opposed, and the idea was dropped. ${ }^{23}$ Indeed, Bishop Ropp was known throughout his life for his sympathies toward Byelorussians and their cultural aspirations. He was not a fighter for Byelorussian cultural values, but being of democratic inclinations he acknowledged and accepted the needs of the Byelorussian masses. Okrainy Rossii vigorously denounced Bishop Ropp for saying that 'instead of insisting upon the Great Russian language, the school authorities should introduce the Byelorussian language in the state schools. ${ }^{24}$

Similar to the position of Skirmunt and Ropp as far as the Polish Circle in the first Duma was concerned was that of Alexander Lednicki, a deputy from the Minsk gubernija who was an outstanding figure in the Duma, a 'brilliant and colourful orator, the best in the Duma, whose mastery of rhetoric was like a knight's mastery of his sword.'25

When he came from Moscow to enter the race in his native Minsk gubernija, Lednicki's candidacy was fully supported by the most influential North-Western noble, the 'Byelorussian Boyar', Edward Woyniłłowicz. Lednicki recorded in his diary:

'I was moved when he said that in spite of my many years' absence from the Region, I had not broken away from it, I was still its true son and the Region would gladly put its mandate in my hands. ${ }^{26}$

When Lednicki obtained that mandate and found himself in St Petersburg confronted by a proposal to join the deputies from the Kingdom of Poland in one Polish Circle, he, as Mr D. wrote in Dzieńnik Kijowski, "changed his mind and embraced the idea of a "territorial Circle", intending to induce it to undertake a wide variety of actions. ${ }^{27}$ In doing so, perhaps under the influence of Skirmunt and Bishop Ropp, he reflected to some extent the idea of his closest friend Woyniłłowicz of whom he wrote:

'Edward Woyniłłowicz... had this local sort of patriotism. Speaking and thinking only in Polish, like Skirmunt he considered himself a Byelorussian and could not endure Polish aggrandizers (wszechpolaki) who harmed both the Polish idea and that of Byelorussia by inflaming nationality tensions. That humanist, as well as I, strove for peace among the nationalities. ${ }^{28}$

Significant also in this context are the views of Woyniłłowicz on his own historic family:

'The Woyniłłowiczes came neither from the East, nor from the West. They are truly natives, whose blood and marrow derive from this people who once buried their dead in mounds ... and

23. Ad. Stankievič, 'Biełaruski chryścijanski ruch', Chryścijanskaja dumka, 20 April 1938, p. 4.

24. Okrainy Rossii, 2 July 1906, p. 315.

25. A. Citron, 72 dnja pervogo Russkogo Parlamenta, 3rd edition, StP, 1906, p. 54.

26. W. Lednicki, Pamiętniki, II, p. 543.

27. Okrainy Rossii, 13 August 1906, p. 412.

28. W. Lednicki, Pamiętniki, II, p. 542. 
who today turn their native Byelorussian soil with wooden ploughs. ${ }^{.29}$

One such 'truly native' representative in the first Duma was Lednicki's friend, Prince Hieronim Drucki-Lubecki. In spite of his vast landed possessions, or maybe because of them, in 1905-1906 the Prince became a convert to the idea of Christian Socialism. ${ }^{30}$ Holding that 'the most important question was the agrarian question'31 which should be resolved in accordance with the specific ideals of each particular nationality, Drucki-Lubecki viewed the solution of the agrarian problem in the North-Western Region as closely bound up with the Byelorussian national peculiarities:

'I myself was brought up among the people and I knew that these simple rural people of Byelorussia have their own ideals. Their ideal is that "the land belongs to God", but so do the people; therefore Byelorussians believe that God's land should belong to God's own people, that the needs of a particular region and the needs of its nationality should be satisfied according to the ideals of the given nationality. ${ }^{\prime 32}$

We see that the deputies of Polish nationality representing the Byelorussian gubernijas belonged to a specific category. Natives of Byelorussia (or Litwa - Lithuania, as some of them would have preferred to have said), of Polish culture, their electoral and parliamentary activity in 1905-1906 was very much under the political influence of Byelorussian interesis. They were spokesmen for Byelorussia's autonomy. In his Memoirs Professor Wacław Lednicki wrote of his father:

'The position my father took after the election in Minsk was supranational... As we have seen, he held that the interests of the whole land were a single entity, not divided by the particularism of its constituent nationalities. ${ }^{133}$

And again about the first Duma's League of Autonomists of which Alexander Lednicki was chairman:

'The policy of the new Duma faction was decentralization (italicized in the original $-J$. Z.). Hence my father's programme concentrated not upon a nationality, but upon the distinctiveness of regional interests. This is why Polish deputies from Litwa and Ruś did not join the Polish Circle, but, together with the Byelorussians and Lithuanians, joined the autonomists' faction. ${ }^{\mathbf{3 4}}$

The thirteen autonomists who were elected from the five gubernijas of the North-Western Region to the first State Duma, all well educated, wealthy and prestigious, constituted a powerful and articulate voice in the Russian parliament. Their strength as a centrifugal force was greatly enhanced by the fact that they were

29. Ibid, p. 551.

30. M. K. Pawlikowski, Dzieciństwo i mlodość Tadeusza Irteńskiego, London, 1959, pp. 189-90.

31. SO, I, p. 197, 4 May 1906.

32. Ibid.

33. W. Lednicki, Pamiętniki, II, p. 556.

34. Ibid., p. 557. 
authentic representatives of the masses. Even Okrainy Rossii, despite its hostility, in the case of Roman Skirmunt for instance, had to admit that 'the Russian masses of the Minsk gubernija influenced the election of Mr Skirmunt so that he could consider himself a true representative of the population.' 35 It was no surprise, therefore, when the great nationality debates began in the first Duma that this organ of the monarchists and guardian of the Empire's inviolability deplored the political drift of the North-Western Region:

'The results of the election have proved that Russian interests in the Region were disregarded... Moreover, both electors and deputies to the State Duma themselves unceremoniously maintain that they would demand reforms in the direction of the maximum possible autonomy. Of regional autonomy, in the sense of some local self-rule, many of them do not even want to hear any more; the idea of political autonomy is flying about; often one can hear the word "separatism". '36

In the Duma the idea of political autonomy for the North-Western Region was tied by its proponents to land reform, the most urgent and most complex problem with which the first Russian parliament had to wrestle. ${ }^{37}$ For all this, the influence in the Duma of those who favoured autonorny was greater than the thirteen in our table would suggest. First of all, they were much more vocal and more articulate than the other representatives of the five gubernijas. Secondly, none of the latter directly opposed autonomy. All five Jewish deputies spoke on behalf of nationality rights. The Cadets had to support the autonomists to justify their Party's electoral pledges. Unaffiliated peasants hampered by lack of education were almost completely dominated by land hunger, leaving others to decide the politicoconstitutional structure of the Empire under which the land would be distribuited to them. And two out of our five North-Western Trudoviks, Gotoveckij and Žukovskij, favoured autonomy as a basis for land reform. Gotoveckij from the Vilna gubernija said:

'Our peasants, first of all, are clearly conscious that they themselves must be masters over their land and decide their own fate... especially in a matter so important and vital to them as the agrarian question. Therefore, they categorically demand that local elective institutions, created especially for this purpose, be empowered to handle the matter locally. From the central authorities they need only the most general guidelines.' ${ }^{38}$

Trudovik Zukkovskij spoke of his representing all the social strata of the Hrodna gubernija 'all of whose views, customs and history are at variance with those of the Russian gubernijas.' On this ground he pleaded with the Duma to pass a law which would put land distribu-

35. Okrainy Rossii, 13 August 1906, p. 412.

36. Okrainy Rossii, 30 April 1906, pp. 159-60.

37. See A. Citron, op. cit., pp. 61-62, 68; T. V. Lokot, Pervaja Duma, Moscow, 1906, p. 70; S. M. Sidel'nikov, Obrazovanije i dejatel'nost' pervoj Gosudarstvennoj Dumy, Moscow, 1962. p. $275 \mathrm{ff}$.

38. SO, II, p. 883,1 June 1906 . 
tion in the hands of locally elective bodies. ${ }^{39}$ The above confirms the evidence of Burbis, a leader of the Byelorussian Socialist Hramada, who wrote in 1924:

'Inspired by the revolutionary movement, the Byelorussian peasantry showered the first and the second Dumas with petitions and instructions demanding land, autonomy for Byelorussia, and the Byelorussianization of their schools. ${ }^{40}$

Out of 63 autonomists in the first Duma - 14 per cent of the entire body ${ }^{41}$ - 13 deputies came from the five North-Western (Byelorussian) gubernijas of whose representation they made up 36 per cent. With no active opponents among the Region's deputies to the idea of autonomy for the North-Western Region, the voice of its spokesmen became more influential.

\section{THE TWO-FRONT BATTLE FOR AUTONOMY OF THE NORTH-WESTERN REGION}

Demands for decentralization and self-government were loud and clear from the very onset. The opportunity to make such demands was immediately at hand - the discussion of the address of the Duma answering the Tsar's speech from the Throne. The draft of the address prepared by the Cadets was submitted for discussion in the Duma on 2/15 May 1906. The document which 'defined the Duma's relation to the Government as well as the character and content of its legislative activity', ${ }^{42}$ contained the following paragraph on the nationality question:

'Finally, the State Duma considers it necessary to emphasize among its urgent tasks the satisfaction of the long overdue claims of various nationalities. Russia represents a state inhabited by various tribes and nationalities. The spiritual union of all these peoples is possible only through satisfaction of the needs of each of them to preserve and develop its individuality in the

39. SO, I, pp. 859-60, 30 May 1906.

40. A. Burbis, 'Biełaruskaja Sacyjalistyčnaja Hramada ŭ pieršym pieryjadzie jaje pracy, 1903-1907' in A. S'tašeŭski et al. (eds), Biełaruś, Minsk, 1924, p. 180.

41. S. M. Sidel'nikov, op. cit., p. 192.

The number of autonomists is 62 in V. I. Ger'je, op. cit., p. 72.

V. S. Golubev, 'Pervaja Gosudarstvennaja Duma', Byloje, StP, February 1907, p. 7, explains: 'A more important (than Social-Democratic - J. Z.) force in the Duma were the autonomists - a group of 63 or, practically speaking, 120 deputies. The first figure, however, established by Borodin, defines the group more accurately because the rest were members of other parties and groups.'

Z. Eukawski, op. cit., p. 55, writes: 'At the beginning, the group of autonomists numbered 125-135 members. Its membership changed continually because it lacked the organizational structure necessary to secure unity for the group.'

A still larger number of autonomists was seen through the frightened eyes of Okrainy Rossii (24 September 1906, p. 493) which counted in the first Duma 'more than 200 autonomist deputies' among whom were also 'native Russian people - Ukrainians, Byelorussians, Cossacks, and even Great Russians from the central gubernijas of New Russia and from Siberia.'

42. S. M. Sidel'nikov, op. cit., p. 213. 
various aspects of its life. The State Duma will take up the problem of satisfying all these justified needs. ${ }^{43}$

To remedy the vagueness of this draft, three Polish members of the address committee of 33, two from the Kingdom of Poland and one, Prince Drucki-Lubecki from the Minsk gubernija, had tried to amend it by incorporating a specific reference to Poland's autonomy, to which the Cadets were already pledged, but they were voted down by almost all the committee's members. ${ }^{44}$ As a result of the insistence of the Cadets, the most influential group in the address committee and in the Duma, on leaving the Duma's views on the nationality problem unclear, the only recourse left to the autonomists was to be as outspoken as possible on the floor of the Duma. Alexander Lednicki undertook this task on 3/16 May 1906, when he took the rostrum and said that in connection with the speeches of the representatives of the various parties 'it was impossible not to add the voice which has been sounding throughout the liberation movement, the voice of the nationalities' grief, of their oppression and privation.' 15 With his customary flamboyance, speaking on behalf of all the nationalities and specifically addressing the Russian people, the Minsk gubernija deputy also stressed the aspirations of his own region:

'I see the hands of our brothers stretching out from those native places of ours, the hands of the labouring classes, the workers and the peasantry who are clamouring to the Russian people for help, clamouring that we all rise together at this solemn moment in the struggle for freedom for all, for building the great foundations of justice. ${ }^{46}$

Reading into the draft of the address what its authors intentionally skipped over - that 'Russia consists of various peoples whose ethnographic and historical conditions differ, who live separately and develop individually' ${ }^{\prime 7}$ — Lednicki denounced 'international cannibalism' and defended 'the just aspirations of various regions for full freedom in organizing an independent national life and building it up on the principles of autonomy and self-government. ${ }^{48}$

Lednicki was immediately seconded by the Vilna gubernija deputy, Baron Ropp, who even at that early stage of the discussions proposed a formula coupling the nationality and agrarian questions, a formula which proved to be the strongest basis for the demands of autonomy. Baron Ropp admitted that 'we have a very complicated and very distinctive peasant question which ... cannot be resolved in the same way in the various localities of the same huge Empire.' ${ }^{49}$

An interesting dialogue soon developed between the nationalities' spokesman, Alexander Lednicki, and a leading Cadet liberal, Professor Karejev appropriately representing the Empire's metropolitan

43. SO, I, p. 76, 2 May 1906.

44. Z. Łukawski, op. cit., p. 51.

45. SO, I, p. 102, 3 May 1906.

46. Ibid.

47. Ibid.

48. Ibid., p. 103.

49. Ibid., p. 109. 
region. The dialogue illustrates how deeply nationality problems and nationality tension underlay Russia's constitutional transformation. ${ }^{50}$

In his speech greeting 'the representatives of the Russian people', Lednicki said that it was his 'duty to state that we expect satisfaction of our national demands from the Russian people', that 'there must not only be liberation of classes, but also liberation of peoples. ${ }^{51}$ In a rather lengthy speech, taking issue with Lednicki's attitude, Professor Karejev retorted benevolently:

'Here from this rostrum a representative of one of the Russian Empire's nationalities addressed you as the "representatives of the Russian people", distinguishing himself from us. No! We see here the representatives of the peoples of Russia as a whole, and a part of the assembly cannot set itself against the rest. ${ }^{.52}$

The Cadet Karajev thought that 'Russia should grant full freedom for their national self-determination to all the peoples which inhabit her', and blamed the 'old habit of identifying (the state of) Russia with the (expression) "Russian land". ${ }^{53}$ He referred to the passage in the draft of the address to the Tsar in which the October 1905 Manifesto was described as being concerned with the transformation of the destiny of 'the Russian land' and was received enthusiastically by 'the whole Russian peop!e'. ${ }^{51}$ The St Petersburg deputy, Professor Karejev, suggested therefore the use of 'expressions more appropriate on this occasion'. ${ }^{55}$ He moved that the expression 'Russian people' be replaced by 'all the people inhabiting the Russian Empire... to indicate the fact that Russia is inhabited by various peoples' ${ }^{56} \mathrm{He}$ also said that as a result of his discussions with representatives of various nationalities,

'We came to the conclusion that it would be much better not to use the expression "Russian land" because the territory of the Russian Empire does not belong exclusively to the Russian nationality and, consequently, we cannot call this land Russian., ${ }^{57}$

In the voting, however, the proposal of the address committee dominated by the Cadets was only partially accepted; the expression 'the whole Russian people' was changed to 'the whole people', but 'the Russian land' was left as it was. ${ }^{58}$

It should be remarked here that with his defence of the cause of

50. The dialogue shows at the same time what a blatant distortion of history it is for historians either to skip the nationality aspect of the Dumas altogether, as F. Kalinyčev dicl in his volume of cocuments (Gosudarstvennaja Duma $v$ Rossii $v$ dokumentach, i materialach, Moscow, 1957) by not including a single original document from the Duma records pertaining to the nationality question, or to brush it aside by deprecatory remarks and contemptuous references, as Sidel'nikov did in his monograph on the first Duma (S. M. Sidel'nikov, op. cit., pp. 215, 218, 241, 313).

51. SO, I, p. 103, 3 May 1906.

52. Ibid., p. 122.

53. Ibid.

54. SO, I, p. 74, 2 May 1906.

55. SO, I, p. 123, 3 May 1906.

56. Ibid., p. 152 .

57. Ibid.

58. SO, I, p. 153, 3 May 1906. 
nationalities, Karejev also tried to shield the integrity and continuity of the Empire. Basically, he had nothing against identifying the Empire with 'the Russian land', but the time for that had not come yet because of the unsolved nationality question. 'Only then', he said, 'will is be possible to call (the state of) Russia the Russian land when all these nationalities, whilst remaining Poles, Jews, Germans, Georgians and so forth, consider themselves Russian citizens. ${ }^{59}$

The only point that national minority deputies gained in shaping the address of the first Duma to the Tsar was the addition of "nationalities' to the imprecise paragraph dealing with the nationality question (see above). One of the sentences now read:

'The spiritual union of all of these peoples and nationalities (plemjon $i$ narodnostej) is possible on through satisfying the needs of each of them to preserve and develop its individuality in the various aspects of its life.' 60

On the day after Lednicki spoke and the issue of 'Russian people' and 'Russian land' had been settled, on 3/16 May 1906, the Duma continued its discussions on the address to the Tsar and heard representatives from the gubernijas of Minsk, Hrodna, Mahiloŭ and Vilna. It was on $3 / 16$ May that Prince Drucki-Lubecki, the deputy from the Minsk gubernija spoke on behalf of the Byelorussian nationality whose agrarian ideal, he said, was unmistakably 'the ideal of private property'. ${ }^{61}$

Three out of four speakers of the Byelorussian gubernijas, DruckiLubecki (Minsk), Songailo (Hrodna), and Jaloveckij (Vilna), stressed the necessity to settle the agrarian dilemma in accordance with the needs and desires of the local population'.2 The amendments they proposed in furtherance of these ideas, however, were voted down by the Duma as aimed at political autonomy. ${ }^{63}$ The fourth speaker was Korenkov, a deputy of the Mahiloŭ gubernija, a Byelorussian peasant whose speech was typical of the whole group of peasant deputies (one of them a Lithuanian) from the five North-Western gubernijas. Korenkov spoke briefly (as did most of his colleagues, when they spoke at all - five of the twelve never took the floor and desperately, almost tragically pleaded:

'Our first need is the land, our second - education ... Peasants, the first thing to ask the Emperor for is that he help us to fight our adversaries. Our numbers are great, but there are very few educated people among us; we don't understand anything...'64

Meanwhile those who did understand fought an intricate political battle for autonomy, wherein the North-Western Region constituted an extremely delicate element.

Immediately after the adoption of the address to the Tsar, in which

59. SO, I, p. 74, 2 May 1906.

60. SO, I, p. 241, 5 May 1906 .

61. SO, I, p. 197, 4 May 1906.

62. Ibid., pp. 197, 198, 206.

63. Ibid., p. 211.

64. Ibid., p. 200 . See also the speech by Z̆ukovskij. a Hrodna gubernija deputy (SO, I, pp. 309, 316, 12 May 1906). 
no mention of Poland's autonomy was made, Lednicki, a leading autonomist and a member of the Central Committee of the Cadet Party, published in the Cadet organ, Rečc (6 May 1906, OS), an open letier to the Party's leader (although not a Duma deputy) Paul N. Miljukov. Lednicki asked Miljukov whether the Cadet Party by its refusal to mention Poland's right to political autonomy in the address had not reneged on its promise. In the same issue of Rec $\breve{c}^{\prime}$ Miljukov assured the Poles that 'the Party had not changed its stand and that the question of Polish autonomy was very much alive'. ${ }^{65}$ Indeed, the quest for autonomy was the firmest bond among the members of the parliamentary Polish Circle. The question of autonomy, according to Eukawski, constituted 'the principal political programme of the Polish representation in the Russian Duma', and one of the Circle's main objectives was to 'unite allies for the cause of the autonomy of the Kingdom of Poland'. ${ }^{66}$ The natural allies in this case, of course, were the Polish deputies from Lithuania, Byelorussia, and the Ukraine, of whom there were eighteen. ${ }^{67}$

As early as 26 April/9 May 1906, just a day before the Duma's opening, the first joint meeting of all the Polish deputies took place. The chief point on the agenda was the establishment of a common Polish parliamentary group. At the meeting, however, it became evident that there were too many differences, as a result of which the Polish deputies from the nine Western gubernijas, instead of joining the Polish Circle, set up a separate group. It called itself the Group of Deputies from the Western Regions, ${ }^{68}$ but was more often referred to as the Territorial Circle, or the Territorialists. ${ }^{69}$ The Territorialists maintained close contacts with the Polish Circle and in important matters held joint sessions.

As Eukawski established, the reason given by the Territorialists for refusing to join the Polish Circle was that they had not been elected exclusively by Polish voters and therefore could not represent Polish interests alone. Iukawski thought, however, that there was another reason, which had been less prominently displayed but which, in effect, was the essential reason - 'the apprehension of Poles inhabiting the so-called Western Region that they might be accused of harbouring separatist tendencies' ${ }^{70}$

It is difficult, however, to accept this statement in view of the following fact. The political goal of the Territorialists, as evidenced by their activity in the Duma, was no different from that of the Polish Circle - autonomy. Their establishment, therefore, as a separate Territorialist Circle did not abate any of the accusations of separatism on the part of Russian nationalists. It only added the Polish nationalists' accusations of separatism to those of the Russians.

In the summer of 1906, during the heated controversy in the Polish

65. Z. Łukawski, op. cit., p. 52. See also W. Lednicki, Pamiętniki, II, p. 559.

66. Z. Eukawski, op. cit., p. 47.

67. Ibid., p. 36.

68. Ibid., pp. 37-8.

69. Okrainy Rossii, 3 September 1906, p. 466.

70. Z. Łukawski, op. cit., p. 37. 
press over the Territorialists' tactics, a certain 'Mr D.', mentioned above, wrote in the Polish Dziennik Kijowski: 'I could never understand this separatism, either during the Duma sessions or now.' Having described the political views of the deputies from the Minsk and Vilna gubernijas, Skirmunt, Baron Ropp, Lednicki, and Massonius, and hinting at an 'extremely pernicious separatism', $\mathrm{Mr} \mathrm{D}$. regretfully admitted 'a strong current clearly manifested in the Duma, which despite protests by some deputies, I cannot call other than antinational, because it seeks separation of the "occupied provinces" (that is how the Poles call Lithuania, Byelo- and Little Russia - the editor of 'Okrainy Rossii') from the Kingdom of Poland, negation of Polish national interests in provinces where we are not colonists and not foreigners, but native people from the beginning. ${ }^{72}$

The mastermind of organizational strategy and political philosophy of the Territorialists was Alexander Lednicki, a Minsk gubernija deputy. In one of the conferences of the Polish deputies from the nine Western gubernijas, Lednicki explained the situation and the tactics to adopt as follows:

'In spite of the fact that it would be easier and more pleasant for us to organize in the name of nationality, nevertheless that must not be done. If we unite in the name of nationality, that will undermine our position in the country; we will become defenders of a minority and wiil lose the confidence of our electors and consequently our mandates. We must unite only territorially and in our parliamentary programme defend the needs of our entire country. Let the people see in us the Poles, but only those who are defending the principles of universal freedom - so that we can defend the national cause more successfully. ${ }^{, 73}$

This reasoning by Lednicki was essentially accepted and embodied in a programme which was formally signed on 4/17 May 1906. ${ }^{74}$ Among the signatories were such autonomists as Prince DruckiLubecki, Skirmunt, Bishop Ropp and Massonius, deputies from the Byelorussian gubernijas, some of whom were adherents of a 'pernicious separatism' not only from Russia, but also, as we have just seen, from the Kingdom of Poland. Speaking of Baron Ropp in the Duma in 1910, Stolypin said that the Baron acted on behalf of "not only the Kingdom of Poland's autonomy, but also the autonomy of other regions'.5

The Territorial Circle was actually a tactical political compromise between exclusive-Polish interests, remnants of the historical Polish Commonwealth from the times before Catherine II, and the nonPolish (Byelorussian, Lithuanian and Ukrainian) ethnographic character of the Western gubernijas.

When, on 11/24 May 1906, the Faction of Autonomists was organiz-

71. Okrainy Rossii, 13 August 1906, p. 412.

72. Ibid.

73. W. Lednicki, Pamiętniki, II, p. 568.

74. Ibid., p. 569 .

75. SO, Third Duma, Session 3, Part 4, col. 785, 7 May 1910. 
ed in the Duma under the leadership of Lednicki, the Polish Circle refused to join it, contending that 'Poland has considerably greater right to autonomy than any other nationality in the Russian state' ${ }^{76}$ As to the autonomy of Byelorussia, Lithuania and the Ukraine, Duma deputy Parczewski, the spokesman of the Dmowslis Party of National Demccracy, Poland's chieí organized voice in all of the four Dumas, said in July 1906 that the Polish Circle was 'in principle opposed to autonomy for these territories'.77 'If these lands', said Parczewski, 'obtain political autonomy, the Polish element which is there will be completely dominated by the local Lithuanian, Byclorussian and Ukrainian population'. Therefore, the thing to fight for in those provinces, 'which the Russians call Western', was according to Parczewski, "the widest possible equality of the local nationalities, primarily in the field of education' ${ }^{\prime} 8$

On the latter point, interestingly enough, Lednicki took a similar view, championing 'abolition of all restrictions and all privileges, with the exception of one privilege - that of cultural competition. ${ }^{79}$ Lednicki the autonomist apparently did not share Parczewski's apprehension that in an autonomous Litwa and Rus' 'the Polish element which is there will be completely dominated by the local population'. Was there any reason to doubt one's forces? During the past centuries Poland had gained a great deal through 'cultural competition' in the eastern Kresy (or Western gubernijas). It gained the allegiance of almost the entire upper and the bulk of the middle strata, the nobility and landed gentry, who embraced Polish culture and at the sarne time were 'native people from the beginning', coming 'neither from the East, nor from the West', like the Woyniłłowiczes, and were economically and educationally superior to the landless and semi-literate masses of Byelorussian, Lithuanian and Ukrainian peasants. Now, in 1906 these Polish elements constituted a sure guarantee of the success of Polish policy in its further 'cultural competition' - if only autonomy and equality could be achieved.

Autonorny, therefore, became the watchword of the Polish deputies from the Western gubernijas. The idea was supported by the Lithuanian, Latvian and some of the Byelorussian and Ukrainian deputies.

Since the main problem of the Duma was agrarian, the question of autonomy was defended as organically linked with the latter: agrarian reform could only be carried out under conditions of autonomy. 'The local situation and forms of ownership and tillage', argued Rev. Trasun, a Viciebsk gubernija deputy, 'are so different in

76. Z. Łukawski, op. cit., p. 56.

77. Ibid.

'Historical Lithuania (Lithuania and Byelorussia) is considered by the National Democrats not as a living social organism, but merely as an historic territorial unit which cannot claim an independent existence.' M. Roemer, op. cit., p. 373.

78. Z. Eukawski, op. cit., p. 56, quoted from the Polish newspaper, Stowo, Warsaw, 30 July 1906.

79. Pervaja Gosudarstvennaja Duma. Alfavitnyj spisok i podrobnyje biografii $i$ charakteristiki členov Gosudarstvennoj Dumy, Moscow, 1906, p. 107. 
Russia that one law for all could never be written. ${ }^{90}$ The deputy was convinced that the agrarian question could be solved only locally by an autonomous government.' ${ }^{\prime 1}$ Speaking of the Cadet agrarian reform bill' ${ }^{82}$ one of the Vilna gubernija deputies, Baron Ropp, objected: 'But if we look at this bill from our viewpoint, from the point of view of the Western Region, we see that it is absolutely inapplicable. ${ }^{\prime 33}$ When Gralewski, representing the Kingdom of Poland, proposed to amend the agrarian bill by stressing that 'elected representatives of the people will adjust the solution of agrarian matters to local conditions and the will of the local population', ${ }^{84}$ Baron Ropp, rebuffing criticism of the amendment, came to his support:

'In such a large state as Russia it is impossible to live without local differences, and people in our Western gubernijas will not live according to the rules which are applicable to the Volga region or the Caucasus. ${ }^{85}$

'Without establishment of autonomy or without regional selfgovernment', stated Jaloveckij, another Vilna gubernija deputy, 'a correct solution of the agrarian question is, in my view, absolutely unthinkable'.86 (For the autonomist views of peasant deputies from the Vilna and Hrodna gubernijas, Gotoveckij and Žukovskij, see above.) Speaking on behalf of 'our Western gubernijas', a Hrodna gubernija deputy, Rev. Songailo, pleaded with the Duma 'not to solve this (agrarian) question as one integral whole, but allow us to solve it as a part of a common problem on the basis of autonomy. ${ }^{37}$

It is worth noting that none of the deputies from the Western gubernijas spoke against autonomy, though some of them were suspicious of landlord autonomists and their attempts to evade direct tackling of the agrarian dilemma.

The whole problem of autonomy was more than a political issue. It had its national, philosophical and psychological ramifications as well.

The Cadet agrarian bill that was discussed by the Duma envisaged the creation of a 'national land fund' out of the expropriated lands. ${ }^{88}$ From this 'fund' land would be distributed 'for longterm use without any right of alienation for a period established by the responsible institutions' ${ }^{89}$ To most of the Western gubernijas' deputies the Cadets' agrarian plan spel!ed nationalization, which they considered a specifically Russian feature, reflecting Russia's land commune

80. SO, I, p. 419, 16 May 1906.

81. SO, II, p. 984, 5 June 1906.

82. The bill, the main one discussed in the Duma, was also known as the 'Bill of the 42 ', since it was sponsored by 42 deputies. It is significan't that none of the deputies from the five North-Western gubernijas was among the 42 sponsors. See F. I. Kalinyčev, op. cit., pp. 171-2.

83. SO, I, p. 491, 19 May 1906.

84. SO, II, p. 2069,6 July 1906.

85. Ibid., p. 2073.

86. SO, I, p. 603, 24 May 1906.

87. SO, II, p. 996, 5 June 1906 .

88. F. I. Kalinyčev, op. cit., p. 169.

89. Ibid., p. 171. 
tradition, foreign to the customs and mentality of the Western parts of the Empire where private property was the rule. During the debates over the land reform, Girnius, a Lithuanian, as a deputy from the Suvalki gubernija, noted that 'almost all the speakers from central Russia are for nationalization, but the Ukrainians and others are against it' ${ }^{90}$ General acknowledgement of this fact is also found in Sidel'nikov's monograph:

'A number of peasant deputies, especially from the NorthWestern gubernijas, as well as wealthy peasants from the Central belt expressed a desire to receive land for private ownership.'91

The philosophical and psychological underpinnings for this desire for private ownership in the North-Western Region with its poor sand, podsol and marsh lands, was aptly explained to the Duma by Lopas, from the Kovno gubernija:

'We inevitably face the task of converting our sand, clay, podsol and marshes into fertile fields and meadows, and this we can achieve only by the unremitting toil of generations. This is the basis of our demand for property rights in the land and our boundless love for it, because without that love there can be no intelligent worker on the land. ${ }^{92}$

How this fundamental fact of agricultural life worked its way into the national consciousness of the people, becoming a political postulate, could be seen from the words of Prince Drucki-Lubecki, the Minsk gubernija deputy who had already spoken in the Duma on behalf of the Byelorussian nation:

'This feeling of inalienability (of land) has penetrated so deeply into the consciousness of the North-Western Region's population, that they call this (God's land) their own, and the principle of private property ownership is so profoundly accepted by them that they actually believe that the whole territory inhabited by the population should belong exclusively to them.' ${ }^{\prime 3}$

Defence of autonomy of the North-Western Region was also coupled with the problem of civil rights. During the extensive discussion of the Belostok pogrom of 1-2/14-15 June 1906, in which 82 Jews and 6 Christians were killed, ${ }^{94}$ Baron Ropp maintained that the pogrom had been indirectly caused by lack of self-government:

'So long as the Region is governed under the central Government's protection by people who actually have nothing in common with the Region... coming from Petersburg, Tiflis, Tobol'sk, and from all parts of Russia, people who do not know the Region and cannot understand its needs, so long as all this persists, in addition to much other evil and injustice, there always will be the danger of pogroms. ${ }^{, 95}$

90. SO, II, p. 878, 1 June 1906.

91. S. M. Sidel'nikov, op cit., p. 308.

92. SO, I, p. 939, 2 June 1906.

93. SO, I, p. 624, 24 May 1906.

94. SO, II, p. 1584, 21 June 1906.

95. SO, II, p. 1732, 26 June 1906. 
The speaker exposed the Russifiers who for many years had been acting with impunity and who, he claimed, had lost their sense of morality under the unlimited protection of the authorities. Baron Ropp saw only one solution:

'To eliminate pogroms, to enable the Region to develop normally and properly, to insure peace among all the classes, and among all the nationalities which inhabit our region, it is necessary that local people govern themselves.'96

Baron Ropp found an eloquent supporter in Srag, a Ukrainian deputy from the Cernigov gubernija, adjacent to the North-Western Region: 'I can accept the brilliant description of this clique of Russifiers made by Baron Ropp. I can agree that prevention of pogroms can be achieved only when local government passes into local hands.' ${ }^{\prime \prime}$ Srag expressed the hope that the Old Regime would be replaced by a new one characterized by freedom, decentralization and autonomy of peoples and regions. ${ }^{98}$ What actually happened, however, proved to be a far cry from these hopes. On 9/22 July 1906 the Tsar's Manifesto dissolving the first State Duma told the realm that, among other things, its deputies instead of legislative work 'had strayed into an area outside their proper jurisdiction and had undertaken to examine the activities of local authorities commissioned by us, pointing out to us the shortcomings of the Fundamental Laws, which can only be amended by our monarchical will.'99

The very first article of the Fundamental Laws - 'The Russian State is one and indivisible' - must have been a grim memento to the autonomists of the first Duma.

96. Ibid., p. 1733.

97. SO, II, p. 1812, 29 June 1906.

98. Ibid., p. 1813.

99. F. I. Kalinyčev, op. cit., p. 182. 